\title{
EFFECT OF THE PROCESSING PARAMETERS ON THE MICROSTRUCTURE AND PROPERTIES OF THE ZL116 ALUMINIUM ALLOY AFTER VACUUM SUCTION CASTING
}

\author{
VPLIV PROCESNIH PARAMETROV NA MIKROSTRUKTURO IN \\ LASTNOSTI AI ZLITINE ZL116 PO VAKUUMSKEM LITJU
}

\author{
Tingting Pan ${ }^{1}$, Tao $\mathrm{He}^{\mathbf{1}^{*}}$, Yuanming $\mathrm{Huo}^{1}$, Xiaojun $\mathrm{Shi}^{2}$, Shoushuang Chen ${ }^{3}$, Kuanping $\mathbf{Y u}^{1}$, \\ Anna Sun ${ }^{1}$ \\ ${ }^{1}$ Shanghai University of Engineering Science, College of Mechanical Engineering, 333 Longteng Road, Songjiang District, Shanghai 201620, \\ China \\ ${ }^{2}$ Fangta Traditional Chinese Medicine Hospital of Songjiang, Songjiang District Shanghai, 39 East Zhongshan Road, Shanghai 201600, China \\ ${ }^{3}$ Chinese Academy of Social Sciences, Institute of Quantitative \& Technical Economics, 5 Jianguomennei Street, Beijing, 100732, China \\ hetao@sues.edu.cn \\ Prejem rokopisa - received: 2018-05-05; sprejem za objavo - accepted for publication: 2018-07-20
}

doi:10.17222/mit.2018.094

\begin{abstract}
The selection of different processing parameters has an important influence on the microstructure and properties of castings. The aim of this investigation is to study the effect of the processing parameters of vacuum suction casting (VSC) on the microstructure and mechanical properties of the ZL116 aluminium alloy. The ZL116 aluminium alloy rods were prepared under an arc current of 300-400 A and a suction diameter of 3.0-3.5 mm using a vacuum-suction-casting machine. The microstructures of the alloys rods were observed with a scanning electron microscope (SEM). The mechanical properties of the alloy specimens were measured with a universal tension tester, a microhardness tester and an electrical resistivity tester. The experimental results show that the microstructure of the ZL116 aluminium alloy is more compact and uniform under an arc current of $300 \mathrm{~A}$ and a suction diameter of $3 \mathrm{~mm}$. The mechanical properties and the electrical resistivity are also improved due to an increase of the strengthening phase. The microhardness reached $93.62 \mathrm{HV}$, the tension strength reached $199.79 \mathrm{MPa}$, and the total elongation at the breaking point reached $30.60 \%$.
\end{abstract}

Keywords: vacuum suction casting, ZL116 aluminium alloy, microstructure, mechanical properties

Izbira različnih procesnih parametrov ima pomemben vpliv na mikrostrukturo in lastnosti ulitkov. Namen avtorjev te študije je bil raziskati vpliv procesnih parametrov vakuumskega (črpalnega) litja na mikrostrukturo in mehanske lastnosti aluminijeve zlitine ZL116. Palice te zlitine so pripravljali v obloku s tokom od $300 \mathrm{~A}$ do $400 \mathrm{~A}$ in premerom črpanja taline $3 \mathrm{~mm}$ in $3,5 \mathrm{~mm}$ z uporabo vakuumskega črpalnega litja. Mikrostrukturo izdelanih palic so opazovali pod vrstičnim elektronskim mikroskopom (SEM). Njihove mehanske lastnosti pa so določili s konvencionalnim trgalnim strojem, merilnikom mikrotrdote in merilnikom električne upornosti. Eksperimentalni rezultati so pokazali, da je mikrostruktura ulitih palic iz Al zlitine bolj kompaktna in enovita pri danih pogojih (300-400 A obloku in $3 \mathrm{~mm}$ premeru črpanja) vakuumskega litja. Mehanske lastnosti in električna upornost zlitine so bile prav tako izboljšane zaradi utrjevalne faze. Dosežena mikrotrdota zlitine je bila $93,62 \mathrm{HV}$, natezna trdnost 199,79 MPa in celotni raztezek do pretrga 30,60\%.

Ključne besede: vakumsko litje, aluminijeva zlitina ZL116, mikrostruktura, mehanske lastnosti

\section{INTRODUCTION}

The ZL116 aluminium alloy is popular as one of Al-Si-Mg series of alloys due to its advantages of good casting fluidity, good air tightness, low shrinkage and low hot-cracking tendency. ${ }^{1,2}$ It is most often used in casting. ${ }^{3}$ In recent years, the pursuit of light weight in the aerospace and automotive industries also gives the ZL116 aluminium alloy a wide range of applications. ${ }^{4-6}$ However, there are a large number of solid solutions, an uneven distribution of the microstructure and other defects, ${ }^{7}$ which seriously affect the mechanical properties of the castings. It has become an urgent problem that needs to be solved for aluminium-alloy castings. The solution is to select a reasonable set of process parameters during the vacuum suction casting (VSC). ${ }^{8}$
Experimental results in previous research showed that the distribution and shape of the eutectic Si particles in the matrix affect the mechanical properties of the cast ZL116 aluminium alloy. ${ }^{9}$ The small spherical and uniformly distributed $\mathrm{Si}$ particles can improve the mechanical properties of the alloy, ${ }^{10}$ but the impurity introduced during the casting will seriously deteriorate the mechanical properties of the alloy, ${ }^{11}$ and other defects such as residual holes, shrinkage porosity and other defects also have an adverse impact on the alloy. ${ }^{12}$

In order to improve the microstructure of aluminium alloys, numerous researchers have made a lot of efforts, including adding alloy elements. ${ }^{13-15}$ Additionally, the method of VSC can also refine the microstructure of the alloy by setting the process parameters of the VSC. . $^{16-19}$ However, there is a lack of studies on the effect of the 
processing parameters after VSC on the microstructure and properties for the ZL116 aluminium alloy.

The aim of this work was to investigate the effect of the processing parameters of the VSC on the microstructure and properties for the ZL116 aluminium alloy. Firstly, the VSC experiment was performed to prepare ZL116 aluminium alloy rods by changing the process parameters of the arc current and the suction diameter. Secondly, the microstructure observation and mechanical property tests for the ZL116 aluminium alloy castings were carried out to provide a reference for the optimization of the processing parameters of the VSC. Finally, some conclusions are drawn.

\section{EXPERIMENTAL PART}

\subsection{Specimen Preparation}

The chemical composition of the ZL116 aluminium alloy is shown in Table 1. The vacuum suction casting equipment used in this experiment is a high-vacuum arc-smelting and suction-casting system. The experimental instrument was vacuum pumped to $8.0 \times 10^{-4} \mathrm{~Pa}$, filled with argon, and its vacuum was $-0.05 \mathrm{MPa}$ to maintain the pressure. The preparation process for the ZL116 aluminium alloy rods was divided into four steps. (1) Commercial pure aluminium ( $\geq 99.9 \%$ ), silicon, magnesium and titanium particles are mixed according to the mass fraction in Table 1. In order to avoid contamination, the copper mould and the arc furnace cavity should be wiped and blown dry with alcohol. (2) The prepared materials were put into the crucible of the electric arc furnace in the VSC system. (3) The residual gases, such as oxygen in the furnace, are removed by smelting a titanium ingot, and the matched materials are repeatedly melted and electromagnetically stirred. (4) The molten alloy liquid is transferred to the suction pot in the arc furnace. Then, the argon in the mould chamber was removed to create a negative differential pressure of $0.05 \mathrm{MPa}$, and the molten alloy liquid was sucked quickly into the copper mould in the lower mould chamber by the pressure difference and gravity $(0.196 \mathrm{~N})$.

Table 1: Chemical composition of the ZL116 alloy (mass fraction, \%)

\begin{tabular}{|c|c|c|c|c|}
\hline Elements & $\mathrm{Si}$ & $\mathrm{Mg}$ & $\mathrm{Ti}$ & $\mathrm{Al}$ \\
\hline Mass fraction & 6.5 & 0.35 & 0.1 & $\geq 90.25$ \\
\hline
\end{tabular}

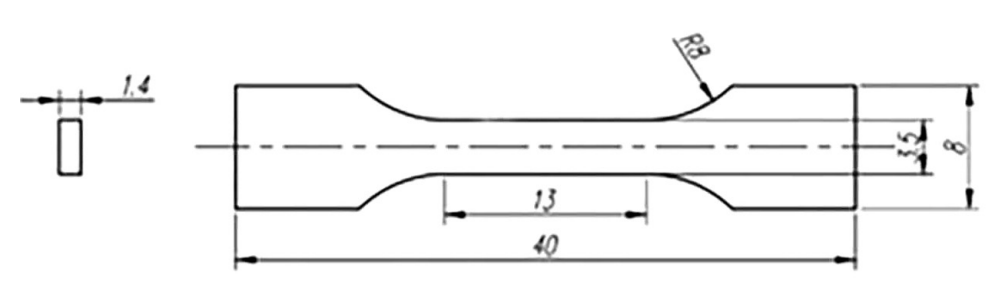

Figure 1: Shape and dimensions of the tension specimen
The main process parameters of the VSC include arc current, suction, suction diameter and other parameters. Hereby, two parameters, the arc current and the suction diameter, were investigated and changed to determine the effect on the microstructure and the properties of the ZL116 alloy. The experimental arrangement of the different process parameters is shown in Table 2. The arc current is selected as $300 \mathrm{~A}, 350 \mathrm{~A}$ and $400 \mathrm{~A}$, and the suction diameter is $3 \mathrm{~mm}$ and $3.5 \mathrm{~mm}$. A total of 6 groups of vacuum-casting experiments were carried out. Every group of VSC experiments was repeated three times.

Table 2: Experimental arrangement for the setting of the different process parameters

\begin{tabular}{|c|c|c|}
\hline Number & Arc current (A) & Suction diameter (mm) \\
\hline 1 & 300 & 3 \\
\hline 2 & 350 & 3 \\
\hline 3 & 400 & 3 \\
\hline 4 & 300 & 3.5 \\
\hline 5 & 350 & 3.5 \\
\hline 6 & 400 & 3.5 \\
\hline
\end{tabular}

The size of the ZL116 aluminium rods after the VSC experiment was $\varphi 10 \times 80 \mathrm{~mm}$. The solid-solution heat treatment was performed for the VSC specimens. The instrument used is a SX2-series of box-type resistance furnaces. According to the heat-treatment specification of the GB/T aluminium alloy, the T6 heat treatment of the ZL116 aluminium rods was carried out. First of all, the holding temperature was set to $515{ }^{\circ} \mathrm{C}$, with a holding time of $6 \mathrm{~h}$, and then it was placed in warm water at $60{ }^{\circ} \mathrm{C}$ for quenching. After that, the artificial aging treatment was carried out. The aging temperature was $175^{\circ} \mathrm{C}$, the holding time was $5 \mathrm{~h}$, and the air cooling was carried out at the end.

\subsection{Microstructure observation and property tests}

After the heat treatment, the tension properties were tested. The tension specimens were cut longitudinally using a wire-cutting machine. The shape and the size of the tension specimen are shown in Figure 1. The tension specimens were polished with abrasive paper of type \#1200 to eliminate the cut marks left by the wire cutting. The tension test was carried out on a JVJ-50s universal 
testing machine. A tensile speed of $1 \mathrm{~mm} / \mathrm{min}$ was selected and tested at room temperature. The microhardness and electrical resistivity of the specimens were measured using a MHVD-1000IS microhardness tester and a FT-300 series resistivity tester.

After the tension test, the microstructure observation was carried out. The observed specimens were prepared as a small piece of $2 \mathrm{~mm} \times 2 \mathrm{~mm} \times 2 \mathrm{~mm}$. The observed specimens were polished using sand paper of type \# 600, \# 800, \# 1200 and \# 2000 on a grinding machine. The polished surfaces were prepared to a mirror-like condition. Then they were washed repeatedly with alcohol, then dried by a blower, and then etched in a $0.5 \% \mathrm{HF}$ solution for $6 \mathrm{~min}$. They were then washed repeatedly with water and alcohol, and finally dried. A SU8070 SEM was used to observe the microstructures of the specimens.

\section{RESULTS AND DISCUSSION}

\subsection{Effect of the arc current on the microstructure and properties of the ZL116 Aluminium Alloy}

A non-consumable electrode arc was used during the vacuum melting. In the process of melting, the higher the arc current, the higher the pouring temperature, ${ }^{20}$ which leads to the superheating of the liquid alloy. When the superheating of the liquid alloy becomes higher, the viscosity of the liquid alloy will be reduced. Thus, their flow performance and the filling ability were improved. However, when the arc current is too high, the molten metal is easy to oxidize, and some of the alloy elements are partially burned. Conversely, the alloy solution was not melted fully, and some of the alloys elements were not fully integrated into the metal alloy liquid. This has an impact on the microstructure and the mechanical properties of the alloy. According to the literature, when the arc current is $300 \mathrm{~A}$, the pouring temperature can reach $750{ }^{\circ} \mathrm{C}$, and at $350 \mathrm{~A}$ and $400 \mathrm{~A}$, the pouring temperature can reach $860{ }^{\circ} \mathrm{C}$ and $990{ }^{\circ} \mathrm{C}$ respectively. ${ }^{21}$ Therefore, it is necessary to select an appropriate arc current to control the quality of the casting in VSC.

Figure 2 and Figure 3 show micrographs of the ZL116 aluminium alloy under an arc current of $300 \mathrm{~A}$, $350 \mathrm{~A}$ and $400 \mathrm{~A}$ at the suction diameter of $3 \mathrm{~mm}$. Figure 2 shows the microstructure magnified 500 times by the SEM. The dark-grey substrate is the Al matrix. The strengthening phase with a bright white structure is distributed in the matrix. Silicon particles with a darkgrey irregular granular structure are uniformly distributed in the matrix, as shown in Figure 2. Figure 2a shows that there are a large number of dendritic crystals, granular Si phases and a solid solution. The strengthening phase in Figure 2b is obviously more than that in Figure 2a. In Figure 2c, there are fewer strengthening phases, a lot of maple-leaf crystals and some defects in the matrix.

Figure 3 shows a SEM microstructure image magnified by 5000 times. It can be seen from Figure 3 that the microstructure distribution of the ZL116 aluminium alloy is more uniform, and the strengthening phase is
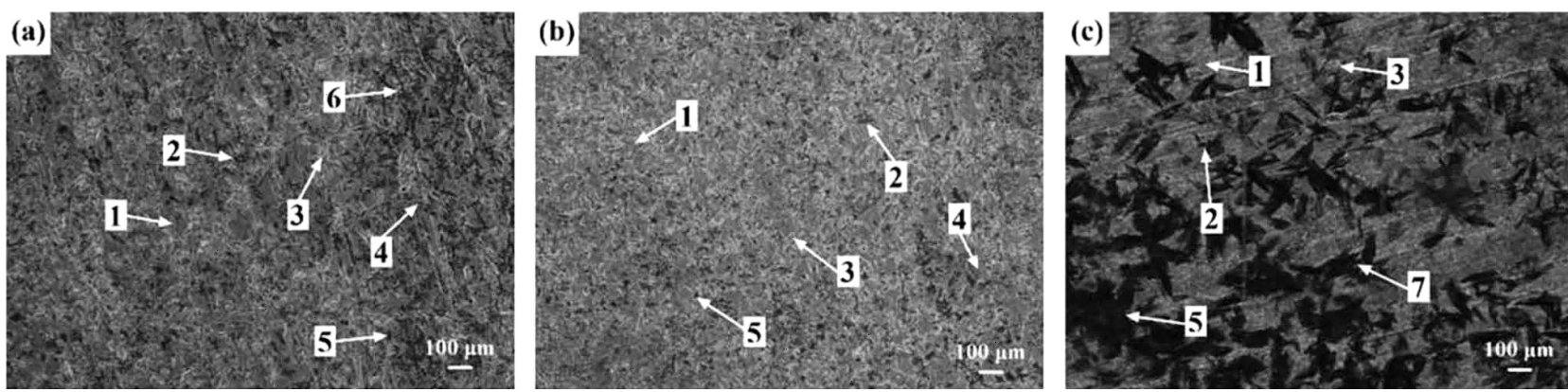

Figure 2: Micrographs of the ZL116 aluminium alloy magnified by 500 times under a different arc current of a) 300 A, b) 350 A and c) 400 A at a suction diameter of $3 \mathrm{~mm}(1$ - Al crystal; 2 - Solid solution; 3 - Strengthening phase; 4 - Si particles; 5 - Defect; 6 - Dendritic crystal; 7 Maple-leaf crystal)
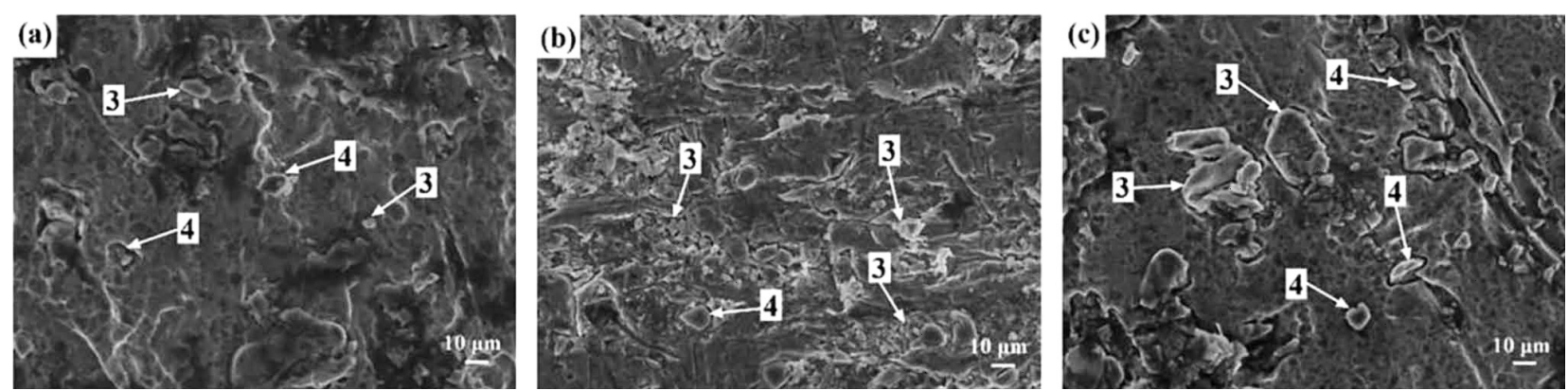

Figure 3: Micrographs of ZL116 aluminium alloy magnified 5000 times under a different arc current of a) 300 A, b) 350 A and c) 400 A at a suction diameter of $3 \mathrm{~mm}$ ( 3 - Strengthening phase; 4 - Si particles) 
also more uniform when the arc current is $350 \mathrm{~A}$. The amount of solid solution at $350 \mathrm{~A}$ is smaller than that of the arc current at $300 \mathrm{~A}$ and $400 \mathrm{~A}$. The casting temperature is improved directly by increasing the arc current. The overheated alloy liquid causes an air gap between the molten alloy and the copper mould due to the thermal expansion, ${ }^{20}$ which reduces the heat-transfer coefficient between the molten alloy liquid and the copper mould, and inhibits the heat conduction. Therefore, the cooling rate is also reduced, which makes the crystal structure of the alloy thicker and form maple-leaf crystals.

Figure 4 shows a variation of the strengthening phase and the solid solution in the volume fraction and the grain size with different arc currents $(300 \mathrm{~A}, 350 \mathrm{~A}$ and $400 \mathrm{~A})$ at a suction diameter of $3 \mathrm{~mm}$. The results come from analysing the microstructure pictures using Image-Pro Plus (IPP) image-analysis software. When the arc current is $350 \mathrm{~A}$, the strengthening phase and the solid solution's volume fraction increase to $8.29 \%$ and $30.51 \%$, their grain sizes reduce to $5.5 \mu \mathrm{m}$ and $6.00 \mu \mathrm{m}$, and their number are more than that in arc current of 300 A and 400 A. Figure 5 shows the variation of the microhardness, tension strength, total elongation and electrical resistivity with different arc currents at a suction diameter of $3 \mathrm{~mm}$. With an increase of the arc current from $300 \mathrm{~A}$ to $350 \mathrm{~A}$, the microhardness of the alloy increases by $18.85 \%$, the tension strength increases to 199.79 $\mathrm{MPa}$, and the elongation at the breaking point increases to $30.60 \%$, but at the same time, the electrical resistivity of the alloy increases by $2.67 \%$. Then, when the arc current is increased to $400 \mathrm{~A}$, the microhardness, tension strength and total elongation at the breaking
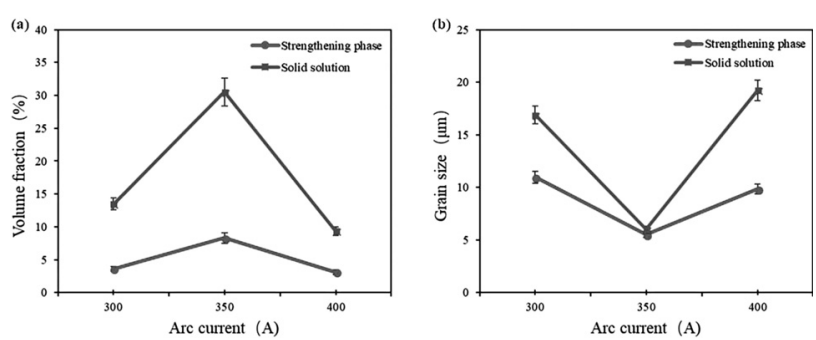

Figure 4: Variation of the strengthening phase and the solid solution in a) volume fraction and b) grain size with the arc current at a suction diameter of $3 \mathrm{~mm}$
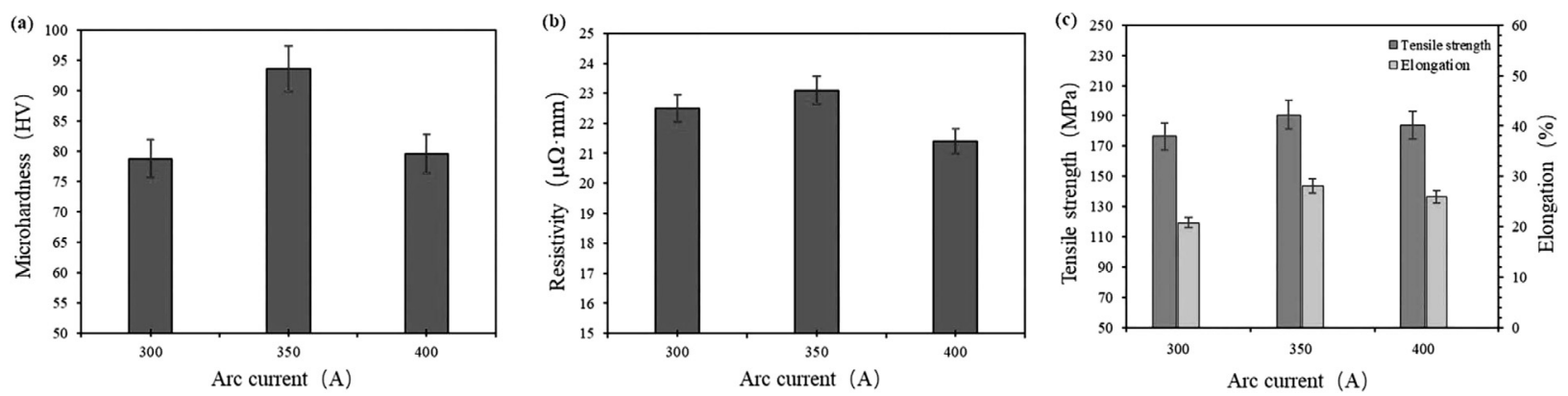

Figure 5: Variation of a) microhardness, b) electrical resistivity, c) tension strength and elongation with arc current at a suction diameter of 3 mm

point of the alloy decrease slowly, in addition, the resistivity of the alloy decreases rapidly. Combined with the microstructure of the alloy (Figure 2, 3 and 4), it can be seen that the microhardness, tension strength and total elongation at the breaking point of the alloy with more refined grains have been obviously improved. This also verifies the relationship between grain size and alloy strength - the Hall-Petch formula. According to the distribution morphology and the refinement degree of the Si phase, the strength and plasticity of the alloy are lower when the silicon phase is thick and unevenly distributed, which has a negative effect on the mechanical properties. However, we can also see that the larger the amount of strengthening phase and the finer the grains, the higher the resistivity of the alloy. Because of the poor conductivity of metal compounds, their electrical conductivity is much smaller than that of their constituent elements, so the resistivity of the metal compounds is much greater than that of the pure elements. In Figure $\mathbf{3}$ and $\mathbf{4}$ it can be seen that in the microstructure of an alloy with an arc current of $350 \mathrm{~A}$, the number of reinforced phases is the most, which leads to its high resistivity.

\subsection{Effect of suction diameter on the microstructure and properties of the ZL116 Aluminium Alloy}

During the experiment, the molten alloy liquid absorbs the casting valve by braking; it thus drives the mechanical pump to remove the argon gas from the mould chamber, forming a negative pressure. The alloy liquid is drawn from the lower pressure smelting furnace through the graphite mouth to the copper mould in the lower-pressure higher die chamber. Because the space in the mould room is fixed, the vacuum degree of the equipment and the power of the mechanical pump are also constant, so the suction in the experiment is also constant. In the case of a constant arc current, the size of the suction diameter will have a great impact on the casting process.

With the change of the suction diameter, the filling speed of the alloy liquid also changes. According to the literature, for a suction diameter of $3 \mathrm{~mm}$, the filling speed is $0.79 \mathrm{~m} / \mathrm{s}$, and for $3.5 \mathrm{~mm}$, the filling speed is $0.77 \mathrm{~m} / \mathrm{s}$. An eddy current occurred readily in the filling process of the alloy liquid, which resulted in defects. ${ }^{21}$ However, when the suction diameter becomes smaller 

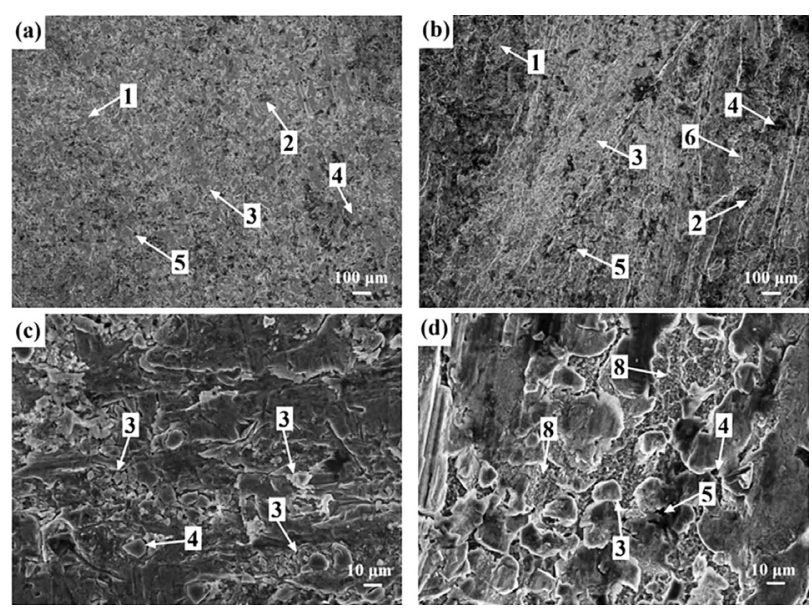

Figure 6: Micrographs of ZL116 aluminium alloy magnified by a, b 500 and c, d) 5000 under different suction diameters of a, c) $3 \mathrm{~mm}$ and b, d) $3.5 \mathrm{~mm}$ at $350 \mathrm{~A}$ arc current $(1-\mathrm{Al}$ crystal; 2 - Solid solution; 3 - Strengthening phase; 4 - Si particles; 5 - Defect; 6 - Dendritic crystal; 8 - Floc bulk crystal)

and the filling speed becomes slower, the alloy liquid will lose heat and solidify quickly during the flow process, which will lead to the formation of castings that cannot be completed. In this experiment, it is difficult to successfully complete the mould filling when the diameter of the suction port is $2.5 \mathrm{~mm}$, and it is determined that the diameter of the suction mouth is $3 \mathrm{~mm}$ and 3.5 $\mathrm{mm}$.

According to the analysis of the arc current above, the structure and properties of the ZL116 aluminium alloy are better when the arc current is $350 \mathrm{~A}$. Here, we choose the same arc current at $350 \mathrm{~A}$.

The microstructures of the alloy castings with different suction diameters are observed. Figure 6a and 6b are microstructural images at 500-times magnification of the ZL116 aluminium alloy castings with diameters of $3 \mathrm{~mm}$ and $3.5 \mathrm{~mm}$, respectively. Figure $\mathbf{6 c}$ and $\mathbf{6 d}$ magnify their microstructures by 5000 times. There are more strengthening phases in the microstructure for the two alloy castings under the condition of an arc current of $350 \mathrm{~A}$. However, there are many tiny pinhole defects in the microstructure of the alloy with a suction diameter of $3.5 \mathrm{~mm}$. It can be seen from Figure $\mathbf{6 c}$ and $\mathbf{6 d}$ that the size of the strengthening phase and
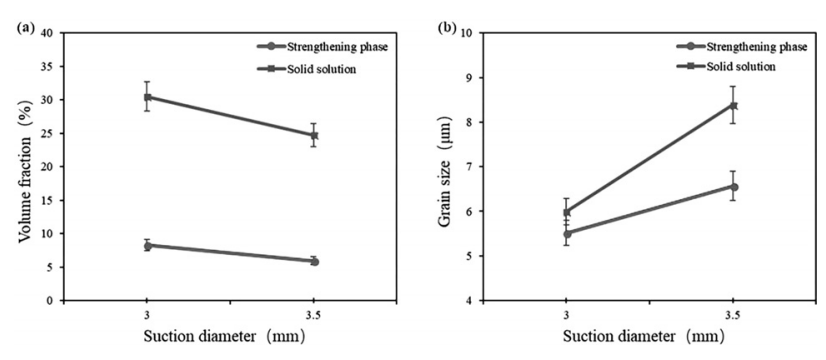

Figure 7: Variation of the strengthening phase and the solid solution in a) the volume fraction and b) the grain size with the suction diameter for an arc current of $350 \mathrm{~A}$

the solid solution are larger in the alloy structure with the suction diameter of $3.5 \mathrm{~mm}$. A lot of floc bulk crystal structure appeared in the matrix. At the suction diameter of $3 \mathrm{~mm}$, both the strengthening phase and the solid solution are relatively small in size. And, a small amount of banded crystal structure was found, but no eddy current is formed. ${ }^{22}$ By reducing the suction diameter and the filling speed, the jet width is increased, the eddy current is reduced, and the defects such as pinholes in the alloy structure are also reduced.

Figure 7 shows the variation of the strengthening phase and the solid solution in the volume fraction and the grain size with different suction diameters $(3 \mathrm{~mm}$ and $3.5 \mathrm{~mm}$ ) for an arc current of $350 \mathrm{~A}$. The results come from an analysis of the microstructure pictures by IPP. And Figure 8 shows the variation of the microhardness, electrical resistivity, tension strength and elongation with different suction diameters for an arc current of $350 \mathrm{~A}$. When the arc current is $350 \mathrm{~A}$, we compare the two alloys, and we can see that the diameter of the suction hole increases from $3 \mathrm{~mm}$ to $3.5 \mathrm{~mm}$, the strengthening phases and solid solutions' volume fraction of the alloy reduce by $2.38 \%$ and $5.76 \%$, their grain size increase by $19.09 \%$ and $39.90 \%$, the microhardness of the alloy decreases by $10.83 \%$, the tension strength is reduced to 190.75 MPa and the total elongation fracture is also slightly reduced to $28.05 \%$, but at the same time there is a greatly reduced resistivity of the alloy equal to $46.32 \%$. From the 5000× SEM microstructures we can see that in the alloy with a larger suction diameter, the crystal is larger, and the volume of the solid solution is
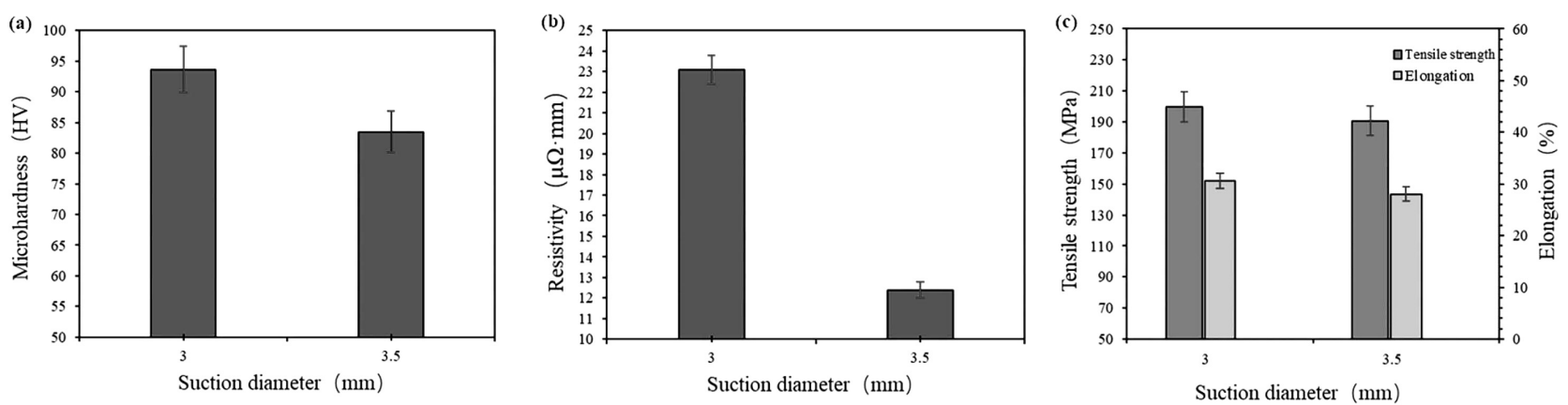

Figure 8: Variation of the a) microhardness, b) electrical resistivity, c) tension strength and elongation with the suction diameter for an arc current of $350 \mathrm{~A}$ 
also larger, but the quantity is less. This greatly reduced the resistivity of the alloy by nearly half. In addition, from the angle of the conductivity, $\mathrm{Si}$ is a kind of semiconductor, its resistivity is $3 \times 10^{12} \mu \Omega \cdot \mathrm{mm}$, which is much higher than that of the aluminium substrate, so the amount of free $\mathrm{Si}$ in the aluminium substrate increases. It can directly reduce the effective conductive area of the aluminium matrix and reduce the conductivity of the alloy. However, the effect of Si on the electrical conductivity of the alloy is also related to the solid-solution treatment process and the morphology of the $\mathrm{Si}$ in the aluminium matrix, and a large area of floc crystal structure appears in the microstructure. The Si particles in this part of the microstructure are small, globular and uniformly distributed in them. We can see that when the Si phase is spherical and smaller in size and uniform in distribution, the conductivity of the alloy will increase and the resistivity of the alloy will decrease.

\section{CONCLUSIONS}

1) With the increase of the arc current, the defects such as pinholes can be gradually reduced under an arc current of $350 \mathrm{~A}$. The microhardness, tension strength and elongation of the ZL116 aluminium alloy are as high as $93.62 \mathrm{HV}, 199.79 \mathrm{MPa}$ and $30.60 \%$, respectively. However, when the arc current reaches $400 \mathrm{~A}$, the microstructure of the alloy appears as a thick maple-leaf crystal structure, which leads to a decrease of the mechanical properties of the alloy.

2) With an increase of the suction diameter, the alloy liquid enters into the mould easily to form an eddy current, which has an impact on its mechanical properties, because of the uneven distribution of the microstructure. When the suction diameter is $3 \mathrm{~mm}$, the eddy-current region can be largely eliminated, and the mechanical properties of the alloy can be improved.

3) The number of strengthening phases and the $\mathrm{Si}$ phase affect the electrical resistivity of the alloy. The uniform distribution of the small spherical Si phase can reduce the electrical resistivity of the alloy; however, too much of the strengthening phases causes a higher electrical resistivity of the alloy.

\section{Acknowledgements}

This project is funded by the Shanghai Committee of Science and Technology (Grant no. 16030501200) and the Shanghai University of Engineering and Science (Grant no. E3-0903-17-01006 \& no. E3-0501-18-01002). The Robot Functional Materials Preparation Laboratory in Shanghai University of Engineering Science is also gratefully acknowledged.

\section{REFERENCES}

${ }^{1}$ H. Möller, G. Govender, W. Stumpf, Comparison of the heat treatment response of SSM-HPDC 6082 and 6004 wrought alloys with A356 and F357 casting alloys, Materials Science Forum, 2011, 53-56

${ }^{2}$ J. A. Österreicher, N. P. Papenberg, M. Kumar, D. Ma, S. Schwarz, C. M. Schlögl, Quantitative prediction of the mechanical properties of precipitation-hardened alloys with special application to Al-Mg-Si, Materials Science \& Engineering A, 703 (2017), doi:10.1016/j.msea.2017.07.080

${ }^{3}$ J. Y. Park, E. S. Kim, I. M. Park, Development of Al-15\%Si Hypereutectic Alloy Automotive Part by Local Squeeze and Vacuum Diecasting, Solid State Phenomena, 116-117 (2006), 110-113, doi:10.4028/www.scientific.net/SSP.116-117.110

${ }^{4}$ Y. U. Wen-Bo, Z. H. Yuan, Z. P. Guo, S. M. Xiong, Characterization of A390 aluminum alloy produced at different slow shot speeds using vacuum assisted high pressure die casting, Transactions of Nonferrous Metals Society of China, 27 (2017), 2529-2538, doi:10.1016/S1003-6326(17)60281-4

${ }^{5}$ M. Campillo, M. T. Baile, S. Menargues, E. MartãN, A. Forn, A357 Aluminium Cast Alloys for Extrusion Processes, Solid State Phenomena, 192-193 (2012), 454-459, doi:10.4028/www.scientific.net/SSP.192-193.454

${ }^{6}$ E. S. Kim, K. W. Lim, K. H. Lee, Characterization of partial squeeze and vacuum die casting process in fabricating automobile parts, in: The International Forum on Strategic Technology, 2007, 433-437

${ }^{7}$ F. Gucmann, D. Gregušová, L. Válik, M. Ťapajna, Š. Haščík, K. Hušeková, K. Fröhlich, O. Pohořelec, J. Kuzmík, DC and pulsed IV characterisation of AlGaN/GaN MOS-HEMT structures with A12O3 gate dielectric prepared by various techniques, International Conference on Advanced Semiconductor Devices \& Microsystems, 2017, 9-12

${ }^{8}$ C. Wang, X. Tan, E. Liu, B. T. Shu, Process parameter optimization and mechanical properties for additively manufactured stainless steel 316L parts by selective electron beam melting, Materials \& Design, (2018), doi:10.1016/j.matdes.2018.03.035

${ }^{9}$ H. T. Teng, B. Q. Xiong, Y. G. Zhang, T. J. Li, Investigation on sub-rapid solidification behavior of semi-solid magnesium alloy metal, Advanced Materials Research, 2011, 156-162

${ }^{10}$ N. Haghdadi, A. Zarei-Hanzaki, M. Kawasaki, A. B. Phillion, P. D. Hodgson, Effect of severe plastic deformation and subsequent silicon spheroidizing treatment on the microstructure and mechanical properties of an $\mathrm{Al}-\mathrm{Si}-\mathrm{Mg}$ alloy, Advanced Engineering Materials, (2017), 1700064, doi:10.1002/adem.201700064

${ }^{11}$ S. Kashyap, C. S. Tiwary, K. Chattopadhyay, Microstructure and mechanical properties of oxidation resistant suction cast $\mathrm{Nb}-\mathrm{Si}-\mathrm{Al}$ alloy, Materials Science \& Engineering A Structural Materials Properties Microstructure \& Processing, 559 (2013), 74-85, doi:10.1016/j.msea.2012.08.027

${ }^{12}$ L. Qian, H. Toda, K. Uesugi, T. Ohgaki, M. Kobayashi, T. Kobayashi, Three-dimensional visualization of ductile fracture in an Al-Si alloy by high-resolution synchrotron X-ray microtomography, Materials Science \& Engineering A, 483 (2008), 293-296, doi:10.1016/j.msea.2006.10.201

${ }^{13}$ S. Kashyap, C. S. Tiwary, K. Chattopadhyay, Effect of Gallium on microstructure and mechanical properties of $\mathrm{Nb}-\mathrm{Si}$ eutectic alloy, Intermetallics, 19 (2011), 1943-1952, doi:10.1016/j.intermet.2011. 05.018

${ }^{14}$ M. Colombo, E. Gariboldi, A. Morri, Er addition to Al-Si-Mg-based casting alloy: Effects on microstructure, room and high temperature mechanical properties, Journal of Alloys \& Compounds, 708 (2017), doi:10.1016/j.jallcom.2017.03.076

${ }^{15}$ Q. Shi, L. Bian, W. Liang, Z. Chen, F. Yang, Y. Wang, Effects of adding Al-Si eutectic alloy and hot rolling on microstructures and mechanical behavior of Mg-8Li alloys, Journal of Alloys \& Compounds, 631 (2015), 129-132, doi:10.1016/j.jallcom.2015.01.094 
${ }^{16}$ S. P. Gerasimov, A. Y. Titov, V. A. Palachev, V. B. Deev, Optimization of the composition of silicon brass LTs16K4 with the purpose of increasing its castability when fabricating art castings, Russian Journal of Non-Ferrous Metals, 57 (2016), 211-216, doi:10.3103/ S1067821216030068

${ }^{17}$ H. Jiang, S. Cao, C. Ke, X. Ma, X. Zhang, Fine-grained bulk NiTi shape memory alloy fabricated by rapid solidification process and its mechanical properties and damping performance, Journal of Materials Science \& Technology, 29 (2013), 855-862, doi:10.1016/ j.jmst.2013.05.007

${ }^{18}$ E. L. Furman, A. B. Finkelstein, M. L. Cherny, The anisotropy of replicated aluminum foams, Advances in Materials Science \& Engineering, 2014 (2014) 1-6, doi:10.1155/2014/230767

${ }^{19}$ G. F. Mi, C. F. Dong, C. Y. Li, H. Y. Wang, Microstructures development in $\mathrm{Al}-5 \mathrm{Fe}$ and $\mathrm{Al}-5 \mathrm{Fe}-3 \mathrm{Y}$ alloys solidified at different cooling rate, Advanced Materials Research, 189-193 (2011), 2462-2466, doi:10.4028/www.scientific.net/AMR.189-193.2462

${ }^{20}$ A. Jahangiri, S. P. H. Marashi, M. Mohammadaliha, V. Ashofte, The effect of pressure and pouring temperature on the porosity, microstructure, hardness and yield stress of AA2024 aluminum alloy during the squeeze casting process, Journal of Materials Processing Tech, 245 (2017) 1-6, doi:10.1016/j.jmatprotec.2017.02.005

${ }^{21}$ Y. Xicong, Basic research on bottom pouring vacuum suction casting technology for small thin wall TiAl based alloy, Harbin Institute of Technology, 2010

${ }^{22}$ W. Xian, C. Pei, Z. Weiwen, L. Bo, L. Yuanyuan, Based on Taguchi method, Al-Cu alloy squeeze casting process parameters are optimized, Special Casting and NonFerrous Alloys, 32 (2012), 60-63, doi:10.15980/j.tzzz.2012.05.018 